\title{
Soft Tissue Route of Administration
}

National Cancer Institute

\section{Source}

National Cancer Institute. Soft Tissue Route of Administration. NCI Thesaurus. Code C38198.

The introduction of a substance into any soft tissue. 